\title{
The Association between Motivation and Sanction on Hand Hygiene Compliance among Nurses at Dr. Pirngadi Hospital, Medan, North Sumatera
}

\author{
Sondang Simanjuntak', Ida Yustina'2), Zulfendri²) \\ ${ }^{1)}$ Masters Program in Public Health, Universitas Sumatera Utara \\ 2)Faculty of Public Health, Universitas Sumatera Utara
}

\begin{abstract}
Background: Hand hygiene is an effective behavior to prevent infection among health workers. This study aimed to determine the associations of motivation and sanction on hand hygiene compliance among health workers at Dr. Pirngadi Hospital.

Subjects and Method: A cross sectional study was conducted at Dr. Pirngadi Hospital, Medan, North Sumatera, Indonesia. A sample of 33 health workers was selected for this study by total sampling. The dependent variable was hand hygiene obedience. The independent variables were sanction and motivation. The data were collected by questionnaire and analyzed by a mulitiple logistic regression.

Results: Hand hygiene compliance was associated with the presence of sanction (OR=3.44; $95 \%$ $\mathrm{CI}=1.22$ to $4.95 ; \mathrm{p}=0.041)$ and motivation $(\mathrm{OR}=4.77 ; 95 \% \mathrm{CI}=2.52$ to $6.30 ; \mathrm{p}=0.029)$.

Conclusion: Hand hygiene compliance is associated with sanction and motivation.
\end{abstract}

Keywords: hand hygiene, compliance, sanction, motivation

\section{Correspondence:}

Sondang Simanjuntak. Masters Program in Public Health, Universitas Sumatera Utara, Jl. Univesitas 21, Medan 20155, North Sumatera, Indonesia. Email: sondangstarlyn@gmail.com

\section{BACKGROUND}

One of the most important indicators of hospital quality is Infection Prevention and Control (PPI), in accordance with the Joint Commission International (JCI) International patient Safety Goals standard, one of which is reducing the risk of infection related to health services.

The Centers for Disease Control and Prevention (Centers for Disease Control and Prevention (CDC) is as a forum for conducting surveillance of health care-related infections (HAIs). The survey results in American hospitals in 2013, 183 hospitals estimated that there were 721,800 cases of infection suffered by 648,000 patients, and a number of 75,000 patients died during hospital treatment (CDC, 2014).

In general, from global data on HAIs, it is stated that the prevalence of HAIs in developing countries with developed countries is not very different. Indonesia as a developing country, the average prevalence of HAIs infection is quite high. Of the 10 Educational RSUs that held active surveillance, the figure was 6-16\% with an average of $9.8 \%$ (Prof. Dr. Soerojo Hospital Magelang, 2016).

Deli Serdang Hospital has a figure of HAI is still quite high, which is $3.14 \%$ (Nurjannah, 2015). Hospitals located in the city of Medan, including, Haji Adam Malik Hospital, have clean surgical wound infections after surgery with a prevalence rate of $5.6 \%$ (Nirbita, 2017). The preliminary survey data conducted by Marzuki in 2017 at Teguh Memorial Hospital Pure Private Hospital, based on HAI's surveillance, showed the incidence of Urinary Tract Infection (UTI) in January 
and March 2016 approaching the Minimum Service Standards (SPM) with incidence reaching $14.7 \%$.

Dr. Pirngadi Hospital, Medan, is a government hospital with B qualifications that become heritage education in Medan City. Based on surveillance of HAI's RSUD Dr. Pirngadi Medan City for 36 rooms in 2017 there is a fairly high incidence of infection, namely Primary Blood Flow Infection (IADP) ranging from $18.45 \%$ to $34.48 \%$, while Operational Area Infection (IDO) is at $2.22 \%-16,6 \%$ The incidence of infection in the Perinatology room, Primary Blood Flow Infection (IADP) is at the rate of $18.51 \%-44.11 \%$ while the standard figure recommended by the Ministry of Health is $\leq 1.5 \%$.

The high incidence of HAI's shows that transmission is still quite high and is a threat to hospital services. This lack of quantity and quality of hospital infection control is closely related to compliance with hand hygiene. According to the World Health Organization (WHO) that compliance with hand hygiene in health workers can control or control the incidence of infection (WHO, 2014).

Hand hygiene compliance is one of the factors that has an influence on preventing HAI's. Studies in the United States show the level of compliance of nurses in carrying out hand hygiene still reaches $50 \%$, in Australia the level of compliance reaches $65 \%$. A study by Karaaslan et al. (2014) in neonatal and child intensive care units, Istanbul Marmara University Hospital, obtained hand hygiene compliance rates of $43.2 \%$. A study by Pittet (2017) average hand hygiene compliance at Geneva University hospitals was $48 \%$.

The number of hand hygiene compliance is still very low in Indonesia. According to a study by Damanik (2012) at Imanuel Hospital, Bandung obtained nurses' compliance rates for hand hygiene of $48.3 \%$, other studies conducted by Primary (2015) in the emergency room of dr. Iskak Tulungagung hospital, resulted compliance rates for hand hygiene of $36 \%$. The causative factor is lack of motivation for hand hygiene nurses.

The initial survey conducted by the researchers through the results of the handwashing skills audit by applying 6 steps by the Infection Control and Prevention Committee (PPI), namely 48\% (48 people) skilled nurses performed 6 steps of hand hygiene with a value of 100 and $18 \%$ (18 people) capable nurses did 4 of the 6 hand hygiene steps with a value of 66.8 . Furthermore, $8 \%$ ( 8 people) nurses were able to do 3 out of 6 steps with a value of 50.1 and $13 \%$ (13 people) nurses were able to do 2 out of 6 steps with a value of 33.4 . Then $5 \%$ (5 people) only know 1 out of 6 steps with a value of $16.7 \%$ and $8 \%$ ( 8 people) nurses do not know at all from 6 steps with a value of o (PPI Committee, 2017).

Hand hygiene compliance can be influenced by characteristic factors, organizational support and behavior. Characteristic factors include knowledge, attitude and workload. Organizational support factors include fixed procedures, awards, sanctions, training and facilities. Behavioral factors include self efficacy and social support (Pittet, 2001).

This study aimed to examine the relationship of motivation and sanctions on hand hygiene compliance among nurses at Dr. Pirngadi Hospital.

\footnotetext{
SUBJECT AND METHOD

1. Study Design

This was a cross sectional study conducted at Dr. Pirngadi Hospital, Medan, North Sumatera, Indonesia.
} 


\section{Population and Samples}

The population in this study were all nurses at Perinatology Room, Dr. Pirngadi Hospital, Medan, North Sumatera. A sample of 33 nurses was selected for this study by total sampling.

\section{Study Variables}

The dependent variable was hand hygiene compliance. The independent variables were motivation and sanction.

\section{Operational Definition of Variables}

Motivation was defined as an encouragement that comes from within and outside the nurse in making hand hygiene. The data were collected by questionnaire. The measurement scale was dichotomous, coded o for weak and 1 for strong.

Sanction was defined as an act of indiscipline in implementing nurses to hand hygiene so that they are given a verbal or written reprimand with indicators of reprimand, administrative sanctions, and strict sanctions as nurses' performance criteria. The data were collected by questionnaire. The measurement scale was dichotomous, coded o for high and 1 for low.

Hand hygiene compliance was defined as the result of observations to implementing nurses in implementing hand hygiene based on indications of five hospitalizations namely before patient contact, before aseptic/invasive actions, after contact with blood or body fluids, after patient contact and after contact with the patient's environment through six steps hand washing, which is flattening soap, rubbing your back and between your fingers, rubbing your palms together, fingers locking each other, rubbing your thumbs in circles. The data were collected by questionnaire. The measurement scale was dichotomous, coded o for poor and 1 for good.

\section{Study Instrument}

The data were collected by questionnaire. Validity and reliability tests were carried out for 20 nurses implementing at the Dr Pirngadi Hospital in Medan. Reliability test was performed to calculate the corrected item-total correlation and cronbach alpha correlation.

\section{Data Analysis}

Univariate analysis were presented in the frequency distribution. Bivariate analysis used product moment correlation. Multivariate analysis used a multiple logistic regression.

\section{Sample Characteristics}

Table 1 showed sample characteristics. Table 1 showed that most of nurses had strong motivation (57.6\%), received high sanction (56.3\%), and good compliance of hand hygiene (75.8\%).

Table 1. Frequency Distribution

\begin{tabular}{lcc}
\hline Variables & n & \% \\
\hline Motivation & & \\
Good & 19 & 57.6 \\
Poor & 14 & 42.4 \\
Sanctions & & \\
Good & 23 & 69.7 \\
Poor & 10 & 30.3 \\
Hand Hygiene & & \\
Compliance & & \\
Adhere & 25 & 75.8 \\
Not Adhere & 8 & 24.2 \\
\hline
\end{tabular}

\section{Bivariate Analysis}

Table 2 showed the results of bivariate analysis. High sanction $(\mathrm{r}=0.55 ; \mathrm{p}=0.005)$ and strong motivation $(\mathrm{r}=0.58 ; \mathrm{p}=0.001)$ increased hand hygiene compliance.

Table 2. The results of bivariate analysis

\begin{tabular}{lcc}
\hline Variable & $\mathbf{r}$ & $\mathbf{p}$ \\
\hline Motivation & 0.58 & 0.001 \\
Sanctions & 0.55 & 0.005 \\
\hline
\end{tabular}

\section{Multivariate Analysis}

Table 3 showed the results of multivariate analysis. Table 3 showed that there motivation $(\mathrm{OR}=4.77 ; 95 \% \mathrm{CI}=2.52$ to $6.30 ; \mathrm{p}=$ 
Journal of Health Policy and Management (2019), 4(2): 91-95

https://doi.org/10.26911/thejhpm.2019.04.02.03

0.029) and high sanction ( $\mathrm{OR}=3.44 ; 95 \%$

$\mathrm{CI}=1.22$ to $4.95 ; \mathrm{p}=0.041$ ) were positively

associated with hand hygiene compliance

Table 3. The results of multiple logistic regression

\begin{tabular}{lcccr}
\hline \multirow{2}{*}{ Independent Variables } & \multirow{2}{*}{ OR } & \multicolumn{2}{c}{ 95\% CI } & \multirow{2}{*}{ p } \\
\cline { 3 - 4 } & & Lower limit & Upper limit & 0.029 \\
Motivation & 4.77 & 2.52 & 6.30 & 0.041 \\
Sanctions & 3.44 & 1.22 & 4.95 & $<0.001$ \\
Constants & 0.02 & & & \\
\hline
\end{tabular}

DISCUSSION

\section{The Effect of Motivation on Hand Hygiene Compliance}

There was an effect of motivation on hand hygiene compliance. The better nurse motivation to avoid infection, the more compliance in hygiene among health personnel.

The results of this study were in line with Chrismadani (2011) which stated that there was a relationship between motivation and compliance.

Susianti (2013) also stated that there was a significant relationship between motivation and nurse compliance in implementing the Save Lives Clean Your Hands.

\section{The Effect of Sanction on Hand Hygiene Compliance}

There was the effect of sanctions on hand hygiene compliance among nurses. The higher sanctions, the more compliance of hand hygiene among nurses.

The result of this study was in accordance with Ernawati (2014) which stated that organizational factors include the sanctions given to health personnels.

Hand hygiene compliance can be influenced by organizational support factors, namely sanctions. Providing sanctions by the organization was a support to improve nurse compliance in carrying out hand hygiene (Pittet, 2001).

\begin{tabular}{l}
\hline REFERENCES \\
\hline CDC (2014). HAI Data and Statistics. \\
Diperoleh dari https://www.cdc. gov/ \\
hai/surveillance/index.html.
\end{tabular}

Chrysmadani EP (2011). Kepatuhan perawat dalam penggunaan alat pelindung diri dasar (Handscoon dan Masker) di RS. Grha Husada Gresik. Diperoleh dari http://lppmunigresblog.wordpres.com.

Damanik SM, Susilaningsih SF, Amrullah AA (2012). Kepatuhan Hand Hygiene di Rumah Sakit Immanuel Bandung. Student e-Jurnals. Diperoleh dari http://journal.unpad.ac.id.

Ernawati (2014). Penerapan hand hygiene perawat di ruang rawat inap rumah sakit. Jurnal Kedokteran Brawijaya. 28(1).

Karaaslan et al. (2014). Compliance of healthcare workers with hand hygiene practices in neonatal and pediatric intensive care units: Overt Observation. Interdisciplinary Perspectives on Infectious Diseases.

Komite PPI (2017). Hasil Audit Kepatuhan Hand Hygiene RSUD Dr. Pringadi. Medan.

Marzuki H (2017). Pengaruh faktor individu, organisasi dan psikologis terhadap kinerja perawat dalam pencegahan healhtcare associated Infection di Rumah Sakit Murni Memorial Hospital. Tesis. FKU. USU.

Nirbita A, Rosa EM, Listiowati E (2017). Faktor risiko kejadian infeksi daerah operasi pada bedah digestif di rumah sakit swasta. Kes Mas: Jurnal Fakultas Kesehatan Masyarakat. 11(2): 9398. 
Nurjannah (2015). Pelaksanaan five moments hand hygiene di RSUD Deli Serdang. Fakiltas Keperawatan. Universitas Sumatera Utara.

Pittet D (2001). Improving adherence to hand hygiene practice: A multidisiplinary approach. Emerging Infectious Desease. 7: 234-40.

Pittet D (2017). Improving adherence to hand hygiene hospital in Mali, Africa Infection Control and Hospital Practice: A Multidisciplinary Approach. Emerging Epidemiology. Infection Control and Hospital Infectious Diseases. 7(2): 234-240.

Pratama BS, Mulyatim K, Kasil R (2015). Faktor determinan kepatuhan pelaksanaan hand hygiene pada perawat IGD RSUD dr. Iskak Tulungagung. Jurnal Kedokteran Brawijaya, 28(2).
RSJ Prof. Dr. Soerojo Magelang (2016). Laporan Pencegahan Dan Pengendalian Infeksi. Diperoleh dari https://rsjsoerojo.co.id.

Sugiyono (2012). Metode Penelitian Kuantitatif Kualitatif dan R\&D. Bandung: Alfabeta.

Susianti M (2013). Hubungan motivasi dengan kepatuhan perawat dalam menerapkan Program Save Live Your Hands di RSU PKU Muhammadiyah Yogyakarta Unit II. Skripsi tidak dipublikasikan. Program Studi Ilmu Keperawatan Stikes Aisyiyah Yogyakarta.

WHO (2014). Hand Hygiene: Why, How \& When?. Diperoleh di: http://webcache.googleusercontent.com. 